\title{
A Question of Causation: Knowing Assistance and the "Duty to Inquire"
}

\author{
Simon Baughen*
}

After the decisions in AGIP (Africa) Ltd. v. Jackson and others ${ }^{1}(A G I P)$ and Lipkin Gorman v. Karpnale Ltd. and another ${ }^{2}$ (Lipkin Gorman), dishonest assistance in a dishonest breach of a fiduciary relationship seems to be what is required to establish liability for knowing assistance. ${ }^{3}$ In assessing the state of a defendant's knowledge reference can be made to the five "Baden" categories of knowledge. ${ }^{4}$ The first three categories indicate dishonesty:

(1) the defendant had actual knowledge of the fraud

(2) the defendant wilfully shut its eyes to the obvious,

(3) the defendant wilfully and recklessly failed to make such inquiries as an honest and reasonable man would make.

The last two categories indicate only negligence:

(4) the defendant knew of circumstances which would indicate the facts to an honest and reasonable man,

(5) the defendant knew of circumstances which would put an honest and reasonable man on inquiry.

What is less clear, however is when the relevant "dishonesty" will be found on the facts. This article seeks to examine two areas of uncertainty arising out of the question of causation. The first concerns a defendant who suspects, but does not actually know, that it is giving assistance to a dishonest scheme but dares not seek clarification for fear that its suspicions might be confirmed. Can such a defendant argue that it is not liable for knowing assistance on the grounds that any questions it had asked

* Lecturer in Law, The University of Bristol. The author wishes to thank Mrs. Helen Norman of the University of Bristol who kindly commented on a previous draft of this article. The views expressed in the article are those of the author alone.

1. [1991] 3 W.L.R. 116.

2. [ 1991 ] 3 W.L.R. 10 (HL). Of particular relevance to the issues addressed in this article is the judgment of the Court of Appeal, [1989] 1 W.L.R. 1340.

3. The Court of Appeal's decision, given by Fox L.J., in $A G I P$ must qualify this assertion to some extent. At p. $131 \mathrm{G}$ he refers to the relevant test of knowledge as that set out in Selangor United Rubber Estates v. Cradock (No 3) [1968] 1 W.L.R. 1555, namely, "circumstances which would indicate to an honest and reasonable man that such a [ fraudulent] design was being committed or would put him on inquiry as to whether it was being committed". However, his subsequent analysis of the facts makes it clear that dishonesty is the relevant factor. At p. $113 \mathrm{G}$ he states, "The question is whether [they] acted honestly". 4. See Baden, Delvaux and Lecuit v. Societe General pour Favoriser le Developpement de Commerce et de l'Industrie en France S.A., [1983] B.C.L.C. 325. 
would have been answered in such a way as to allay its suspicions? The second concerns the extent to which the plaintiff's own negligence can bar or limit its right to sue a defendant for knowingly assisting the fraud.

\section{The "duty to inquire" and causation.}

\section{(a) A difference of approach in AGIP and Eagle Trust?}

This issue appears to be subject to two differing views at first instance (the issue was not considered in Fox L.J.'s judgment in $A G I P$ ). In $A G I P$ Millett J. strongly rejected the idea that a dishonest defendant could raise the defence that any further inquiries it might have made would have failed to flush out the fraudster. The defendant's argument was based on the judgment of Peter Gibson J. in Baden ${ }^{5}$ which discussed the position of a party who is put on inquiry but fails to inquire and concluded that the plaintiff must prove that the inquiry would have disclosed the truth; the burden lying on it to prove a causal connection between the failure to make inquiry and the loss.

Millett J. vigorously rejected the idea that this argument had any relevance to cases of dishonesty as opposed to constructive notice. In his view the argument

"derive [d] from a misunderstanding of the basis of the constructive trustee's liability. He is not liable for failing to make inquiry, but for the misapplication of the plaintiff's property. He is under no duty to make inquiry, his only duty is to act dishonestly. If he makes inquiry, he does so for his own protection. If he does not make inquiry, the loss is not caused by his failure to do so but by his participation in the misapplication of the plaintiff's funds. He is liable only if he acted with knowledge; and this must be judged in the light of all the circumstances known to him and any explanation actually given to him. But it is not, in my view, to be judged considering the hypothetical explanations which might have been given to him if he had sought them. If it were otherwise, his liability would depend on whether the fraudster would have been sufficiently inventive to be able to supply a plausible explanation if asked for one. In the present case it would depend on whether the defendants should be assumed to have directed their inquiries, which ex hypothesi they did not make, to Mr. Zdiri [the fraudster] or to his superiors. Such considerations are or ought to be irrelevant."'6

In contrast, Vinelott J. in Eagle Trust plc v. SBC Securities Ltd. appeared to suggest that such a line of enquiry is relevant to the issue of dishonesty. ${ }^{7}$ Dealing with the allegation that dishonesty was borne out by a failure to make inquiry, he said:

"Savory Milln may have felt some anxiety, and even entertained some suspicion, as to how Ferriday had managed to arrange for the $113.5 \mathrm{~m}$ to be paid by Anser 
on his behalf. But it is to my mind going altogether too far to say that any honest and reasonable man would either have inferred that, despite the denial to Eagle's solicitors, he was indemnifying the sub-underwriters or some of them on behalf of Eagle or that the $£ 13.5 \mathrm{~m}$ was Eagle's money which had been misappropriated by Ferriday in a gross breach of his duty as a director and in contravention of s. 151; or that an honest and reasonable man would not have applied the money in discharge of the liabilities of Earnshaw Haes and Ferriday until he had been satisifed by inquiry that the moneys were properly paid. It is not easy to see what further inquiries Savory Milln could have made. If inquiry had been made of Ferriday and he had been innocent of any wrongdoing, he might well have resented the inquiry; and if guilty, it is hardly likely that, faced with a second inquiry, he would have confessed at all. And . . . if he had refused to answer, what further inquiry could Savory Milln have made? It would hardly have been open to them to invite Eagle to play detective and investigate their own chief executive."'8

\section{(b) The facts of AGIP.}

At first glance, the above passages suggest a conflict of judicial opinion as to the relevance of causation and the duty to inquire. However, a closer examination of the facts of those two cases suggests that this conflict is more apparent than real. Of particular significance, it is submitted, is the state of the defendant's knowledge at the time the so-called "duty to inquire" arose.

In $A G I P$ the fraud arose when Mr. Zdiri, a senior officer of the plaintiff, fraudulently altered the name of the payee on a payment order, after it had been signed, in favour of Baker Oil. Baker Oil had recently been incorporated and its two directors and shareholders were a partner of Jackson's and an employee. Thereafter the money was transferred to Jackson's account and was eventually transferred overseas to various recipients. At the time Jackson's effected these transfers, Millett J. stressed that they already had the requisite guilty knowledge, therefore any "duty to inquire" would strictly be a misnomer. The purpose of any such enquiry would be purely for Jackson's own protection.

Millett's finding was based upon the following facts. For the two years preceding the fraud some US $\$ 10 \mathrm{~m}$ had come from the plaintiffs to Kinz, via companies set up through Jackson's, which ran a jewellery business in France. Jackson's instructions in these transactions came from the recipients and not the plaintiffs.

"They knew of no connection or dealings between the plaintiffs and Kinz or of any commercial reason for the plaintiffs to make substantial payments to Kinz. They must have realised that the only function which the payee companies or Euro-Arabian performed was to act as "cut-outs" in order to conceal the true destination of the money from the plaintiffs. They must also have realised that

8. Ibid. at p.511 A-D. 
the only purpose in having two "cut-outs" instead of one was to make impossible for investigators to make any connection between the plaintiffs and Kinz without having recourse to Lloyd's Bank's records; and their object in frequently replacing the payee company by another must have been to reduce the risk of discovery by the plaintiff." 9

Moreover, a letter of 14th August, 1984 from Knapp-Fisher showed that Mr Jackson was concerned at the possibility that the plaintiffs might obtain disclosure of Lloyds Bank's records, discover what had happened to the money and try to recover it. Against this background, Millett J. found that Jackson and Griffin "obviously knew that they were laundering money. They were consciously helping their clients to make arrangements that they were laundering money ... They must have realised that their clients might be involved in a fraud on the plaintiffs." 10

Although Jackson and Griffin never gave evidence, the external evidence, such as the Knapp-Fisher letter, pointed to the fact that they may have believed that the fraud being committed was a scheme to avoid Tunisian exchange control, possibly with the connivance of the plaintiffs. However, Millett J. attached no significance to the fact that Jackson and Griffin may have got the details of the fraud wrong. What mattered was that they must have known that the banking arrangements set up through themselves could only have been established with a view to perpetrating a fraudulent purpose. This would be enough to establish the necessary dishonesty on their part to make them liable to the plaintiffs in an action for knowing assistance.

Millett $J$. also went on to mention the fact that the defendants never made any enquiries or took any steps to satisfy themselves that the arrangements had the plaintiffs' knowledge and approval. In the light of his subsequent comments on the issue of causation, however it is clear that he did not regard this factor as being essential for establishing dishonesty. Effectively, Millett J. was treating this as a "Baden 2" case rather than a "Baden 3" one.

Despite Fox L.J.'s unfortunate use of the Selangor test for knowledge, it is clear that he regarded the crucial issue as being whether or not the defendant had acted honestly. In this connection he concluded that Millett J. rightly came to the conclusion that the defendants must have known they were laundering money and "were consequently helping their clients to make arrangements to conceal some dispositions of money which had such a degree of impropriety that neither they nor their clients could afford to have them disclosed." "Like Millett J. he placed particular emphasis on Knapp-Fisher's letter to Jackson's of 14th August, 1984:

"Mr. Jackson and Mr. Griffin were being given advice on the possibility that a payment or payments might involve a fraud on $A G I P$. Having got to that point it seems to me that persons acting honestly would have pursued the matter with 
a view to satisfying themselves that there was no fraud. But there is nothing to show that they did that. They made no inquiries of $A G I P$ at all. They let the matter continue." 12

Like Millett J., Fox L.J. referred to the defendants' failure to make inquiries, but unlike Millett J., did not go on to examine how critical that failure was in establishing dishonesty in the defendant.

\section{(c) The facts of Eagle Trust}

In October 1987 the plaintiff company made a take-over bid for a group of companies. The defendant company agreed to underwrite the cash alternative and the rights issue which formed part of the offer. The defendant sub-underwrote its liability, using a list of underwriters introduced by plaintiff's chief executive, Mr. Ferriday. The list included Ferriday himself as underwriting 25.5 million shares. The plaintiff later claimed that the defendant ought to account for $£ 13.5$ million paid under the subunderwriting arrangements. It alleged that Mr. Ferriday had fraudulently arranged for its money to satisfy obligations, including his own arising out of the subunderwriting, and that the defendant ought to have known of this or have been put on enquiry.

In this connection two particular facts were relied on. First, as Mr. Ferriday's wealth was largely tied up in Eagle, after "Black Monday" it ought to have been clear that he would have lacked the funds necessary to satisfy his sub-underwriting obligations. Secondly, Mr. Ferriday had arranged the sub-underwriting list and had altered it at a late stage. The allegation was made that, in the case of Martin Boston \& Co./Martin Boston, the list was changed after they had denied they were liable and their obligation had been taken over by Ferriday. However, when asked by Eagle's solicitors, Mr. Ferriday had denied acting on behalf of that firm.

In contrast to the facts in $A G I P$, this factual base on its own would be insufficient to establish that the defendant must have known that Mr. Ferriday was discharging his liabilities out of Eagle's money; especially in the light of Mr. Ferriday's earlier denial to Eagle's solicitors. The "duty to inquire" serves a different function than on the stronger facts of $A G I P$. There it served only as a possible means whereby a defendant might extricate itself from pre-existing guilty knowledge. In Eagle Trust it serves as a means of establishing whether that guilty knowledge ever existed, a potential "Baden"' 3 case. This, therefore, provides a possible basis for reconciling the two decisions. Causation will be relevant, but only if the "duty to inquire" is itself necessary to establish guilty knowledge by the defendant.

On closer examination, however, this distinction is unconvincing. In Eagle Trust, the defendant was not dishonest and therefore was not liable for knowing assistance. A key factor in this finding was Ferriday's earlier denial to Eagle's solicitors. The issue is not affected by the question of what additional information further inquiries 
could have revealed. It is very difficult to distinguish "Baden 3" knowledge from "Baden 5" knowledge and it is submitted that Millett J. was correct to state in AGIP that issues of causation should only be relevant to questions of constructive notice which have no place in the fraud based action of knowing assistance. Moreover, to treat as relevant this issue of causation runs the risk of diluting the deterrent effect of the action on potential fraudulent assisters.

It is unfortunate that this issue has yet to be clarified at Court of Appeal level. Fox L.J. ignored it altogether in AGIP and the state of the pleadings in Lipkin Gorman precluded any serious examination of what facts could constitute dishonesty. What dicta there are in that case tend to confirm the muddled thinking identified by Millett $\mathrm{J}$. in $A G I P$. May L.J., criticising Selangor, stated that "it was wrong to equate the duty to inquire where there has been fraud and the bank is proved to have known of it with that where all that is being alleged is that the bank has been negligent". ${ }^{13}$ With respect, if the bank is proved to have known of the fraud, that disposes of the issue and any question of a duty to enquire becomes irrelevant. However, the words used by May L.J. identify the key problem with using a "duty to inquire"' to establish dishonesty, namely that it tends to confuse dishonesty with mere negligence. This confusion is illustrated by Fox L.J.'s use in $A G I P$ of the Selangor test which covers both negligence and dishonesty, whereas his subsequent analysis of the facts is directed entirely towards dishonesty alone. It is submitted that the law in this area would be clearer if the concept of a "duty to inquire" were to be abandoned altogether and knowledge categorised broadly as either dishonest or honest but negligent.

\section{Causation, contributory negligence and "clean hands".}

In Lipkin Gorman Cass, a salaried partner in a firm of a solicitors abstracted money from its client account to fund his gambling habits. The solicitor sought to recover the money from either the bank or the Playboy Club where the gambling had taken place. The claim against the bank was framed as one for breach of a duty of care owed to the solicitors as its clients in both contract and tort and also as a claim for knowing assistance.

Alliott $\mathbf{J}$. found for the solicitors in both claims, but limited the amount of their recovery to the losses occurring in the period from the breach of duty by the bank to 1st October, 1980 by which time Cass's fellow partners should have discovered the full extent of his embezzlement for themselves. By that time one of Cass's partners had confronted him with a false claim for travel expenses and had accepted Cass's explanation that that was all that was owed. However, Cass stayed on as a signatory and from that date was able to steal two further sums of $£ 2,102.05$ and $£ 120,698.61$. From that date, their contributory negligence was 100 per cent, so barring the contractual action in which liability was the same as in negligence, independently of the existence of any contract. The knowing assistance claim was also barred on 
the grounds that it would be inequitable to give them any relief. May L.J. endorsed this approach on the grounds that the plaintiff could no longer come to the court with "clean hands". 14

It is submitted that this approach is quite wrong. There is no equivalent to contributory negligence in actions for breach of trust. The nearest equivalent is a defence that the plaintiff consented to the breach of trust. This patently does not cover the plaintiff's conduct in Lipkin Gorman. Nor does the doctrine of "clean hands" operate against a negligent plaintiff. In Williams v. Staite misconduct by a licensee towards the freeholder did not affect its claim to an estoppel licence. ${ }^{15}$ Some element of dishonesty in the plantiff is required before it ceases to have "clean hands" as with the attempt to deceive the court with forged documents in J. Willis \& Sons v. Willis, another licence case. ${ }^{16}$

On the facts of Lipkin Gorman it is easy to see how both Alliott J. and the Court of Appeal came to the conclusion they did. On the evidence of banking practice in that case, some form of dishonesty would be required to establish a breach of duty of care in contract and tort. Therefore it is easy to assimilate that liability with knowing assistance and to conclude that if contributory negligence operates on one action some equivalent must be found for the other. The actions are not identical, however, but only appear to be so because the effect of the evidence as to banking practice is that a bank which honours its mandate can never be negligent unless it is also dishonest. The extended concept of "clean hands" is quite inappropriate to an action based on the dishonesty of one who assists a fraudster. For instance, if in AGIP the plaintiff had been careless in allowing Mr. Zdiri to perpetrate his fraud, neither of the defendants would have been any less dishonest in assisting him. To curtail the plaintiff's recovery would be to punish it for carelessness and allow a fortuitous escape to the fraudster and accomplices.

\section{Conclusion}

Two sets of muddled thinking have been going on in the knowing assistance cases discussed above. The first is to allow the similarities between "Baden 3" and "Baden 5 " knowledge to blur the boundaries between dishonesty and negligence and allow questions of causation relevant to the latter issue to intrude onto the former. The second is the evidential quirk in Lipkin Gorman that a bank honouring its mandate can never be negligent and honest. This has led both Alliott J. and the Court of Appeal to assimilate the bank's contractual liability to its customer with its liability for knowing assistance. However, the basis of these actions is quite different and to seek an equivalent to contributory negligence in knowing assistance is not required on grounds of consistency and has the undesirable effect of diluting any deterrent effect the action for knowing assistance may have.

16. [1986] 2 E.G.L.R. 62. 